\title{
Investigation of asymptomatic temporomandibular disorders with Fonseca anamnestic index in clinical practice
}

\author{
Deniz Yaman (iD , ${ }^{1 *}$ Cansu Alpaslan (iD,${ }^{2}$ \\ Oya Kalaycıoğlu iD ${ }^{3}$ \\ ${ }^{1}$ Department of Oral and Maxillofacial Surgery, Faculty \\ of Dentistry, Bolu Abant Izzet Baysal University, Bolu, \\ ${ }^{2}$ Department of Oral and Maxillofacial Surgery, Faculty \\ of Dentistry, Gazi University, Ankara, ${ }^{3}$ Department of \\ Biostatistics and Medical Informatics, Bolu Abant izzet Baysal \\ University, Faculty of Medicine, Bolu, Turkey
}

\begin{abstract}
ObJective: The study aims to evaluate the presence of temporomandibular disorders (TMD) and their severity in asymptomatic and healthy individuals using the Fonseca anamnestic index.

Materials and Method: A total of 135 individuals (80 females and 55 males, mean age $34.4 \pm 10.9$ ) were involved in the study. The Fonseca anamnestic index was administered to the individuals. The data analysis was conducted by using Pearson's chi-squared test, Fisher's exact test, one-way ANOVA, and Spearman's correlation.

RESULTS: TMD was detected in $63 \%$ of the individuals. Most of them (40\%) had mild TMD. The difference between gender and TMD severity was statistically significant $(p=0.001)$. Temporomandibular joint (TMJ) pain showed a statistically significant positive correlation with headache and emotional stress $(r=0.312, p<0.001 ; r=0.299, p<0.001$, respectively). TMJ pain showed the strongest positive correlation with clicking $(r=0.443, p<0.001)$. Bruxism showed positive correlations with the TMJ pain and clicking ( $r=0.197, p=0.022$ and $r=0.221, p=0.010$, respectively).

Conclusion: The Fonseca anamnestic index is a reliable diagnostic tool that can be used to detect TMD-related symptoms and severity even in asymptomatic and healthy participants, providing rapid results in clinical practice.
\end{abstract}

KEYWORDS: Early diagnosis; temporomandibular joint; temporomandibular joint disorders

Citatıon: Yaman D, Alpaslan C, Kalaycıoğlu O. Investigation of asymptomatic temporomandibular disorders with Fonseca anamnestic index in clinical practice. Acta Odontol Turc 2021;38(3):62-7

Received: October 24, 2020; Accepted: February 02, 2021

*Corresponding author: Dr. Deniz Yaman, Bolu Abant İzzet Baysal University,

Faculty of Dentistry, Bolu, Turkey

E-mail: yamand896@gmail.com
EDITOR: Zühre Akarslan, Gazi University, Ankara, Turkey

Copyright: () 2021 Yaman et al. This work is licensed under a Creative Commons Attribution License. Unrestricted use, distribution and reproduction in any medium is permitted provided the original author and source are credited.

FundING: None declared.

CONFLICT OF INTEREST: The authors declare no conflict of interest related to this study.

\section{INTRODUCTION}

Temporomandibular disorders (TMD) are clinical problems with accompanying signs and symptoms, such as pain in the temporomandibular joint (TMJ) or chewing muscles, restrictions in jaw movements, deviation/defection when opening the mouth, and the occurrence of clicking/popping or crepitation in the TMJ with function. ${ }^{1,2}$ Although TMD is not life-threatening, they typically harm individuals' quality of life due to their chronic course. $^{3}$

The awareness of patients with TMD and their reasons for visiting an oral and maxillofacial surgeon may vary. A sudden difference in occlusion as a result of effects on the muscles controlling the chin position and the presence of pain in the TMJ is a key factor driving patients to visit the clinic. ${ }^{4}$ In contrast, other studies have reported that some TMD signs and symptoms are also detectable in healthy, asymptomatic individuals..$^{5-7}$ Lövgren et al. ${ }^{7}$ reported that $30 \%$ of participants had TMD. Schiffman et al. ${ }^{5}$ reported that $69 \%$ of participants showed signs of TMD, and $34 \%$ of this group had severe TMD. Solberg et al. ${ }^{6}$ reported that $65 \%$ of the participants had TMD signs and symptoms, but only $5 \%$ required treatment. As such, these studies collectively seem to point out that it is more important to evaluate the clinical severity of patients' complaints rather than simply assessing the total signs and symptoms. ${ }^{5-7}$ The Fonseca anamnestic index is one diagnostic tool available for classifying TMD according to their severity. ${ }^{8-10}$ TMJ pain, headache, bruxism, limitation of mandibular movement, presence of malocclusion, neck and nape pain, and emotional stress can be determined with this index. ${ }^{11}$ 
Table 1. Fonseca anamnestic index results; number (n) and percentage (\%)

\begin{tabular}{llll}
\hline Questions & $\begin{array}{l}\text { No } \\
\mathbf{n}(\%)\end{array}$ & $\begin{array}{l}\text { Sometimes } \\
\mathbf{n}(\%)\end{array}$ & $\begin{array}{l}\text { Yes } \\
\mathbf{n}(\%)\end{array}$ \\
\hline 1. Is it hard for you to open your mouth? & $105(77.8)$ & $20(14.8)$ & $10(7.4)$ \\
\hline 2. Is it hard for you to move your mandible from side to side? & $113(83.7)$ & $12(8.9)$ & $10(7.4)$ \\
\hline 3. Do you get tired /muscular pain while chewing? & $98(72.6)$ & $23(17.0)$ & $14(10.4)$ \\
\hline 4. Do you have frequent headaches? & $58(43.0)$ & $44(32.6)$ & $33(24.4)$ \\
\hline 5. Do you have pain on the nape or stiff neck? & $64(47.8)$ & $32(23.9)$ & $38(28.4)$ \\
$\begin{array}{l}\text { 6. Do you have earaches or pain in craniomandibular joints? } \\
\text { 7. Have you noticed any temporomandibular joint clicking while }\end{array}$ & $90(66.7)$ & $24(17.8)$ & $21(15.6)$ \\
chewing or when you open your mouth? & $87(64.4)$ & $23(17.0)$ & $25(18.5)$ \\
\hline 8. Do you clench or grind your teeth? & $84(62.2)$ & $16(11.9)$ & $35(25.9)$ \\
\hline 9. Do you feel your teeth do not articulate well? & $74(54.8)$ & $9(6.7)$ & $52(38.5)$ \\
\hline 10. Do you consider yourself a tense (nervous) person? & $62(45.9)$ & $35(25.9)$ & $38(28.1)$ \\
\hline
\end{tabular}

Table 2. Frequency of participants (number and percentage) who answered positively to items on the Fonseca anamnestic index

\begin{tabular}{lllll}
\hline Questions & $\begin{array}{l}\text { No TMD } \\
(\mathbf{n}=50)\end{array}$ & $\begin{array}{l}\text { Mild TMD } \\
(\mathbf{n = 5 4 )}\end{array}$ & $\begin{array}{l}\text { Moderate } \\
\text { TMD } \\
(\mathbf{n = 1 7 )}\end{array}$ & $\begin{array}{l}\text { Severe } \\
\text { TMD } \\
(\mathbf{n = 1 4})\end{array}$ \\
\hline 1. Is it hard for you to open your mouth? & $0(0.0 \%)$ & $3(5.6 \%)$ & $1(5.9 \%)$ & $6(42.9 \%)$ \\
2. Is it hard for you to move your mandible from side to side? & $0(0.0 \%)$ & $1(1.9 \%)$ & $0(0 \%)$ & $9(64.3 \%)$ \\
\hline 3. Do you get tired /muscular pain while chewing? & $0(0.0 \%)$ & $4(7.4 \%)$ & $4(23.5 \%)$ & $6(42.9 \%)$ \\
4. Do you have frequent headaches? & $1(2.0 \%)$ & $16(29.6 \%)$ & $8(47.1 \%)$ & $8(57.1 \%)$ \\
\hline 5. Do you have pain on the nape or stiff neck? & $2(4.0 \%)$ & $18(33.3 \%)$ & $8(47.1 \%)$ & $10(76.9 \%)$ \\
6. Do you have earaches or pain in craniomandibular joints? & $0(0.0 \%)$ & $2(3.7 \%)$ & $7(41.2 \%)$ & $12(85.7 \%)$ \\
$\begin{array}{l}\text { 7. Have you noticed any temporomandibular joint clicking while } \\
\text { chewing or when you open your mouth? }\end{array}$ & $0(0.0 \%)$ & $4(7.4 \%)$ & $8(47.1 \%)$ & $13(92.9 \%)$ \\
8. Do you clench or grind your teeth? & $2(4.0 \%)$ & $12(22.2 \%)$ & $9(52.9 \%)$ & $12(85.7 \%)$ \\
9. Do you feel your teeth do not articulate well? & $4(8.0 \%)$ & $24(44.4 \%)$ & $11(64.7 \%)$ & $13(92.9 \%)$ \\
10. Do you consider yourself a tense (nervous) person? & $3(6.0 \%)$ & $15(27.8 \%)$ & $11(64.7 \%)$ & $9(64.3 \%)$ \\
\hline
\end{tabular}

TMD: temporomandibular disorders

The purpose of the present study was to investigate the presence of temporomandibular disorders using the Fonseca anamnestic index among asymptomatic and healthy participants and to determine the current severity of TMD in these individuals. In particular, we were interested in how the signs and symptoms associated with TMD show distribution among individuals with varying levels of severity and in ascertaining whether these factors further influence the severity and chronicity of TMD.

\section{Materials and Method}

The study was carried out compatible with the Declaration of Helsinki. Ethical approval was obtained from the Gazi University Faculty of Medicine Clinical Research Ethics Committee (No: 127). A total of 135 patients were included in this study. All participants signed a consent form before the start of the study. Participants who were 18 years of age or older, who did not have a systemic disease, who had come to the clinic due to a complaint other than TMJ disorders, who has not previously received orthodontic treatment, who had no history of TMJ trauma and treatment, and who agreed to answer the index questions were included.
The Fonseca anamnestic index used in this study was administered via an evaluation form consisting of 10 questions, where each question had three options (yes, no, and sometimes). The answers given to the questions were created by taking the scoring guide reported with the original Fonseca anamnestic index report. ${ }^{11}$ After scoring responses, individuals were classified according to the severity of their current TMD. The scoring of this classification is as follows: zero to 15 points, no TMD; 20 to 40 points, mild TMD; 45 to 65 points, moderate TMD; and 70 to 100 points, severe TMD, respectively.

\section{Statistical analysis}

Cronbach's alpha coefficient was obtained by conducting an internal consistency analysis to measure the consistency of the responses to the Fonseca anamnesis index. The IBM SPSS Statistic version 21.0 software program (IBM Corporation, Armonk, NY, USA) was used for statistical analysis. The data of categorical variables were compared using Pearson's chi-squared test and Fisher's exact test, while continuous and normally distributed variables were compared with oneway ANOVA. Spearman's correlation test was used to evaluate correlations between items in the Fonseca anamnestic index. The results were interpreted at the level of $\alpha=0.05$ statistical significance. 
Table 3. Comparison of age, gender and intraoral findings among temporomandibular disorder (TMD) severity levels. Data are shown in mean \pm standard deviation or number (\%).

\begin{tabular}{|c|c|c|c|c|c|c|c|}
\hline & \multirow[b]{2}{*}{$\begin{array}{l}\text { Total } \\
(n=135)\end{array}$} & \multicolumn{4}{|c|}{ TMD severity levels } & \multirow[b]{2}{*}{ Test value } & \multirow[b]{2}{*}{$\mathbf{P}$} \\
\hline & & $\begin{array}{l}\text { No TMD } \\
(n=50)\end{array}$ & $\begin{array}{l}\text { Mild TMD } \\
(\mathrm{n}=54)\end{array}$ & $\begin{array}{l}\text { Moderate TMD } \\
(n=17)\end{array}$ & $\begin{array}{l}\text { Severe TMD } \\
(n=14)\end{array}$ & & \\
\hline Age & $34.4 \pm 10.9$ & $34.7 \pm 11.3$ & $33.9 \pm 11.3$ & $33.7 \pm 9.5$ & $36.6 \pm 10.8$ & $0.267^{\dagger}$ & 0.849 \\
\hline \multicolumn{8}{|l|}{ Gender } \\
\hline Female & $80(59.3)$ & $22(44.0)^{\mathrm{a}}$ & $30(55.6)^{a, b}$ & $15(88.2)^{b}$ & $13(92.9)^{b}$ & \multirow{2}{*}{$17.587^{\ddagger}$} & \multirow{2}{*}{0.001} \\
\hline Male & $55(40.7)$ & $28(56.0)^{\mathrm{a}}$ & $24(44.4)^{a, b}$ & $2(11.8)^{b}$ & $1(7.1)^{b}$ & & \\
\hline \multicolumn{8}{|l|}{ Intraoral findings } \\
\hline Tooth wear & $45(33.3)$ & $13(26.0)^{a}$ & $13(24.1)^{\mathrm{a}}$ & $9(52.9)^{a, b}$ & $10(71.4)^{\mathrm{b}}$ & \multirow{4}{*}{$20.081^{\S}$} & \multirow{4}{*}{0.006} \\
\hline Tooth \& implant fracture & $2(1.5)$ & $1(2.0)^{\mathrm{a}}$ & $0(0.0)^{\mathrm{a}}$ & $0(0.0)^{\mathrm{a}}$ & $1(7.1)^{\mathrm{a}}$ & & \\
\hline Linea alba & $13(9.6)$ & $5(10.0)^{\mathrm{a}}$ & $6(11.1)^{a}$ & $1(5.9)^{a, b}$ & $1(7.1)^{b}$ & & \\
\hline No pathological findings & $75(55.6)$ & $31(62.0)^{\mathrm{a}}$ & $35(64.8)^{\mathrm{a}}$ & $7(41.2)^{\mathrm{a}}$ & $2(14.3)^{a}$ & & \\
\hline
\end{tabular}

${ }^{\dagger}$ One-Way ANOVA, `Pearson's chi-square, and ${ }^{\S}$ Fisher's exact test. Same superscript letter denotes a subset of TMD severity levels whose column proportions do not differ significantly from each other at the $\alpha=0.05$ level based on the Bonferroni adjusted $z$-tests.

\section{Results}

Of the 135 individuals included in this study, 80 were females and 55 were males, aged 18 to 50 years with an average age of $34.4 \pm 10.9$ years. Data of the responses to the Fonseca anamnestic index were shown in Table 1.

TMD was not detected in $37 \%(n=50)$ of study participants, while $40 \%(n=54)$ reported mild TMD, $12.6 \%$ $(n=17)$ reported moderate TMD, and $10.4 \%(n=14)$ reported severe TMD. Malocclusion (44.4\%), which is the most common complaint in the mild TMD group, was followed by pain in the neck and nape (33.3\%). Emotional stress and malocclusion were reported in $64.7 \%$ of the moderate TMD group. In the severe TMD group, clicking sounds in the TMJ $(92.9 \%)$ were detected at the same rate as malocclusion (Table 2).

Of the 33 participants who complained of headaches, 26 were females and seven were males and a statistically significant difference was determined $(p=0.025)$. Further, 19 of 21 people with complaints of pain in the ear and TMJ pain were females, 5 of 25 people who reported TMJ sounds while opening the mouth were males, and just eight of the 38 individuals who experienced emotional stress were males and, when these three factors were assessed according to gender, statistically significant differences were found $(p=0.004$, $p=0.050$, and $p=0.013$, respectively).

Descriptive data for the study participants are presented in Table 3 . The mean age of the participants was $34.4 \pm 10.9$ years, and there was no statistically significant difference between TMD Fonseca severity levels in terms of age $(p=0.849$, Table 3$)$. When TMD Fonseca severity levels were compared according to gender, a statistically significant association was found $(p=0.001$, Table 3$)$. In terms of gender distribution, post-hoc comparisons with Bonferroni adjusted z-tests revealed significant differences between the normal TMD group and patients with mild and moderate TMD. After clinical examination oral findings of all individuals were recorded. In $55.6 \%$ of the patients, no pathological findings were observed, however, tooth wear was the most common intraoral finding as it was observed in $33.3 \%$ of the participants. Also, a statistically significant association was found between intraoral findings and TMD severity levels $(p=0.006)$. Post-hoc comparisons showed that the prevalence of tooth wear was significantly higher in the severe TMD group, compared to normal and mild TMD groups.

In our study, $54.3 \%$ of participants answered 'yes' to the eighth item (bruxism) of the Fonseca anamnestic index. The relationship between this item in the index and the clinical observation of tooth wear was found to be statistically significant $(p=0.004)$.

In our study, the Cronbach's alpha coefficient, which measures the internal consistency of the answers given by the individuals to the Fonseca anamnestic index, was 0.769 . Also, the correlation between the 10 items of the Fonseca's anamnestic index was examined. In our study, a positive correlation of items 1, 2, 3, 6, 7, 8 , and 9 of the index was determined (Table 4). The $4^{\text {th }}$ item of the index (headache) had the strongest positive correlation with the $5^{\text {th }}$ item of the index (stiffness, pain in the neck and nape) $(r=0.443 ; p<0.001)$, while the $6^{\text {th }}$ item of the index (pain in the ear and TMJ) showed the strongest positive correlation with the $7^{\text {th }}$ item of the in$\operatorname{dex}$ (TMJ clicking) $(r=0.443 ; p<0.001)$. The $10^{\text {th }}$ item of the index (emotional stress) also showed a positive correlation with the $8^{\text {th }}$ item (bruxism) $(r=0.263 ; p=0.002)$ and the $5^{\text {th }}$ item (stiffness and pain in the neck), $(r=0.191 ; p=0.027)$. The $9^{\text {th }}$ item (malocclusion) had positive correlations with the $6^{\text {th }}$ item (pain in the ear and TMJ) and $7^{\text {th }}$ item (TMJ clicking) $(r=0.210 ; p=0.014$ and $r=0.281 ; p=0.001$, respectively). 
Table 4. Correlation between items in Fonseca anamnestic index

\begin{tabular}{|c|c|c|c|c|c|c|c|c|c|c|}
\hline & & I1 & 12 & I3 & I4 & I5 & I6 & 17 & 18 & 19 \\
\hline \multirow[t]{2}{*}{12} & $r$ & 0.325 & & & & & & & & \\
\hline & $\mathrm{p}$ & $(<0.001)$ & & & & & & & & \\
\hline \multirow[t]{2}{*}{ I3 } & $r$ & 0.302 & 0.455 & & & & & & & \\
\hline & $\mathrm{p}$ & $(<0.001)$ & $(<0.001)$ & & & & & & & \\
\hline \multirow[t]{2}{*}{ I4 } & $r$ & 0.053 & 0.155 & 0.275 & & & & & & \\
\hline & $\mathrm{p}$ & (0.539) & 0.073 & 0.001 & & & & & & \\
\hline \multirow[t]{2}{*}{ I5 } & $r$ & 0.116 & 0.203 & 0.287 & 0.443 & & & & & \\
\hline & $\mathrm{p}$ & 0.181 & 0.018 & 0.001 & $(<0.001)$ & & & & & \\
\hline \multirow[t]{2}{*}{ I6 } & $r$ & 0.313 & 0.419 & 0.313 & 0.312 & 0.294 & & & & \\
\hline & $\mathrm{p}$ & $(<0.001)$ & $(<0.001)$ & $(<0.001)$ & $(<0.001)$ & $(<0.001)$ & & & & \\
\hline \multirow[t]{2}{*}{17} & $r$ & 0.319 & 0.487 & 0.383 & 0.252 & 0.222 & 0.443 & & & \\
\hline & $\mathrm{p}$ & $(<0.001)$ & $(<0.001)$ & $(<0.001)$ & 0.003 & 0.010 & $<0.001$ & & & \\
\hline \multirow[t]{2}{*}{18} & $r$ & 0.236 & 0.224 & 0.082 & 0.143 & 0.211 & 0.197 & 0.221 & & \\
\hline & $\mathrm{p}$ & 0.006 & 0.009 & 0.346 & 0.099 & 0.014 & 0.022 & 0.010 & & \\
\hline \multirow[t]{2}{*}{ I9 } & $r$ & 0.188 & 0.268 & 0.252 & 0.241 & 0.169 & 0.210 & 0.281 & 0.253 & \\
\hline & $\mathrm{p}$ & 0.029 & 0.002 & 0.003 & 0.005 & 0.050 & 0.014 & 0.001 & 0.003 & \\
\hline \multirow[t]{2}{*}{ I10 } & $r$ & 0.067 & 0.210 & 0.175 & 0.147 & 0.191 & 0.299 & 0.200 & 0.263 & 0.086 \\
\hline & $\mathrm{p}$ & 0.439 & 0.015 & 0.043 & 0.088 & 0.027 & $<0.001$ & 0.020 & 0.002 & 0.321 \\
\hline
\end{tabular}

r: Spearman correlation coefficient, p: population correlation coefficient, p-values are calculated from Spearman's correlation analysis. I1 (Item 1): Is it hard for you to open your mouth?, I2(Item 2): Is it hard for you to move your mandible from side to side?, I3 (Item 3): Do you get tired /muscular pain while chewing?, I4 (Item 4): Do you have frequent headaches?, 15 (Item 5): Do you have pain on the nape or stiff neck?, I6 (Item 6): Do you have earaches or pain in craniomandibular joints?, I7 (Item 7): Have you noticed any temporomandibular joint clicking while chewing or when you open your mouth?, 18 (Item 8): Do you clench or grind your teeth?, I9 (Item 9): Do you feel your teeth do not articulate well?, I10 (Item 10): Do you consider yourself a tense (nervous) person?

\section{Discussion}

In this study, we assessed how the signs and symptoms associated with TMD appear in asymptomatic patients or in those with varying severities of TMD. Most study participants $(40 \%)$ were individuals with mild TMD, whereas individuals without TMD composed the second largest subgroup (37\%). In the study by Pedroni et al., ${ }^{10}$ individuals with mild to moderate TMD were observed at a rate of $62 \%$, while this rate was $40 \%$ in the study by Conti et al. ${ }^{2}$

Conti et al. ${ }^{2}$ also observed that most participants were in the non-TMD group (58.71\%). Similarly, participants with mild TMD $(n=47)$ composed the largest subgroup of the study population of Bevilaqua-Grossi et al.'s study. ${ }^{9}$

After grouping participants according to TMD Fonseca severity, the current TMD findings in each group were determined with percentage rates. With this approach, we aimed to analyze the effective signs and symptoms in the non-TMD group and the groups with different severities of TMD and to obtain detailed information about which factors push patients to seek treatment and create awareness related to their problem. As TMD severity increased, the percentage of all complaints mentioned in Fonseca's anamnestic index increased. However, the most frequently mentioned complaint in all groups was the $9^{\text {th }}$ item (malocclusion). In the severe TMD group, in addition to this, clicking sounds from the TMJ (item 7) were reported often.
TMD boasts a multifactorial etiology; occlusion, trauma, stress, and parafunctional activities are the factors driving the progression of the condition. ${ }^{12,13}$ As stated in the neuromuscular theory, occlusal conflicts trigger pain and spasms by creating an imbalance in the neuromuscular mechanism. ${ }^{14}$ Malocclusion, which is defined as the deviation of occlusion from the functional and aesthetically ideal level, was a major complaint in all TMD groups and in the non-TMD group in our study..$^{15} \mathrm{In}$ addition, 33 people reported headaches, and a statistically significant gender difference was found in terms of headache reports $(p=0.025)$. Separately, a positive correlation was found between the $4^{\text {th }}$ item of the index (headache) and the $6^{\text {th }}$ item of the index (pain in the ear and TMJ) $(r=0.312 ; p<0.001)$. Notably, TMD and headache disorders share the same pain pathway, which is responsible for the sensory innervation of the head and face. ${ }^{16}$ Both painful TMD and tension headache are highly exacerbated by stress and more frequently observed in females. ${ }^{17-19} \mathrm{~A}$ statistically significant positive correlation between the $6^{\text {th }}$ item (pain in the ear and TMJ) and the $10^{\text {th }}$ item (emotional stress) of the index supports this result. This finding supports the view that emotional stress may provoke further changes in muscle activity and occlusion..$^{20,21}$

In our study, the prevalence of TMD was approximately two times greater in females than in males (female (n): 58; male (n): 27). Our results support that TMD findings and symptoms are more prevalent in females. ${ }^{22} \mathrm{Hormonal}$ differences and variations in muscle 
structure and connective tissue are likely among the main causes of this result. ${ }^{22}$ Parafunctional habits, such as bruxism, cause biomechanical changes in structures at the joint surface due to overload. ${ }^{23,}{ }^{24}$ This harmful habit was found at its lowest rate in the non-TMD group $(4 \%)$, whereas this rate was at its highest in the severe TMD group (85.7\%). Bruxism, which was divided into two separate classifications (sleep and awake) in 2018, can be considered a movement disorder or sleep disorder and is also observable in healthy individuals. ${ }^{25}$ De Wijer et al. ${ }^{26}$ pointed out that parafunctional habits can be extremely destructive, yet some individuals may not experience any significant impact on the oral structures. On the other hand, bruxism has been emphasized as an effective clinical risk factor in the development of TMD. ${ }^{27}$ The $8^{\text {th }}$ item of the Fonseca anamnestic index (bruxism) showed positive correlations with the $6^{\text {th }}$ item (pain in the ear and TMJ) and the $7^{\text {th }}$ item (clicking sounds in the TMJ) $(r=0.197 ; p=0.022$ and $r=0.221$; $p=0.010$, respectively). We found bruxism is associated with the development of TMJ pain and TMJ sound complaints, as Soares et al. ${ }^{28}$ previously suggested. Postural changes play an important role in the etiology of TMD by causing changes in the mandible position. ${ }^{29}$ The rate of neck stiffness and pain was the highest in the severe TMD group at $76.9 \%$. Also, the $4^{\text {th }}$ item (headache) of the index is highly associated with the $5^{\text {th }}$ item (pain on the nape or stiff neck) $(r=0.443 ; p<0.001)$. The prevalence of stiffnesses/pain in the neck and nape due to posture changes affect the development of TMD were consistent with previous study results..$^{30}$ Only $10 \%$ to $20 \%$ of the population with TMD symptoms are expected to consult a doctor concerning treatment. ${ }^{3,31}$ Our study revealed that $63 \%$ of individuals who are not aware of the presence of TMD have mild, moderate, or severe TMJ disorders. Therefore, the evaluation of mouth opening and the limitation in the mandibular movement are important to ensure early diagnosis and to prevent TMD from becoming chronic. A limitation of this study is the lack of a larger population. Hence, further studies with larger groups and longer follow-up are needed to confirm the results of this study.

\section{ConCLUSION}

The Fonseca anamnestic index is a reliable diagnostic tool that can be used to detect TMD-related symptoms and severity even in asymptomatic and healthy participants. This index is of great importance in raising awareness of individuals by starting the treatment of TMD-related symptoms at an early stage.

\section{ACKNOWLEDGEMENT}

This study was presented as a poster presentation at the $24^{\text {th }}$ TAOMS International Scientific Congress, May 23-27, 2017, Muğla, Turkey

\section{References}

1. Liu F, Steinkeler A. Epidemiology, diagnosis, and treatment of temporomandibular disorders. Dent Clin North Am 2013;57:465-79.

2. Conti PCR, Costa YM, Gonçalves DA, Svensson P. Headaches and myofascial temporomandibular disorders: overlapping entities, separate managements? J Oral Rehabil 2016;43:702-15.

3. Liu HX, Liang QJ, Xiao P, Jiao HX, Gao Y, Ahmetjiang A. The effectiveness of cognitive-behavioural therapy for temporomandibular disorders: a systematic review. J Oral Rehabil 2012;39:55-62.

4. Chantaracherd P, John MT, Hodges JS, Schiffman EL. Temporomandibular joint disorders' impact on pain, function, and disability. J Dent Res 2015;94:79-86.

5. Schiffman EL, Fricton JR, Haley DP, Shapiro BL. The prevalence and treatment needs of subjects with temporomandibular disorders. J Am Dent Assoc 1990;120:295-303.

6. Solberg WK, Woo MW, Houston JB. Prevalence of mandibular dysfunction in young adults. J Am Dent Assoc 1979;98:25-34.

7. Lövgren A, Österlund C, Ilgunas A, Lampa E, Hellström F. A high prevalence of TMD is related to somatic awareness and pain intensity among healthy dental students. Acta Odontol Scand 2018;76:387-93.

8. Campos JADB, Carrascosa AC, Bonafé FSS, Maroco J. Severity of temporomandibular disorders in women: validity and reliability of the Fonseca Anamnestic Index. Braz Oral Res 2014;28:16-21.

9. Bevilaqua-Grossi D, Chaves TC, De Oliveira AS, Monteiro-Pedro V. Anamnestic index severity and signs and symptoms of TMD. Cranio 2006;24:112-8.

10. Pedroni CR, De Oliveira AS, Guaratini MI. Prevalence study of signs and symptoms of temporomandibular disorders in university students. J Oral Rehabil 2003;30:283-9.

11. Nomura K, Vitti M, Oliveira ASD, Chaves TC, Semprini M, Siéssere $\mathrm{S}$, et al. Use of the Fonseca's questionnaire to assess the prevalence and severity of temporomandibular disorders in Brazilian dental undergraduates. Braz Dent J 2007;18:163-7.

12. De Godoi Gonçalves DA, Dal Fabbro AL, Campos JADB, Bigal ME, Speciali JG. Symptoms of temporomandibular disorders in the population: an epidemiological study. J Orofac Pain 2010;24:270-8.

13. De Boever JA, Carlsson GE, Klineberg IJ. Need for occlusal therapy and prosthodontic treatment in the management of temporomandibular disorders. Part I. Occlusal interferences and occlusal adjustment. J Oral Rehabil 2000;27:367-79.

14. Suvinen TI, Reade PC, Kemppainen P, Könönen M, Dworkin SF. Review of aetiological concepts of temporomandibular pain disorders: towards a biopsychosocial model for integration of physical disorder factors with psychological and psychosocial illness impact factors. Eur J Pain 2005;9:613-33.

15. Barrera-Mora JM, Escalona EE, Labruzzi CA, Carrera JML, Ballesteros EJC, Reina ES, et al. The relationship between malocclusion, benign joint hypermobility syndrome, condylar position and TMD symptoms. Cranio 2012;30:121-30.

16. Bendtsen L. Central sensitization in tension-type headache-possible pathophysiological mechanisms. Cephalalgia 2000;20:486-508.

17. Fernandes G, Franco AL, Aparecida de Godoi Gonçalves D, Geraldo- Speciali J, Bigal ME, Camparis CM. Temporomandibular disorders, sleep bruxism, and primary headaches are mutually associated. J Orofac Pain 2013;27:14-20.

18. Gonçalves DA, Bigal ME, Jales LC, Camparis CM, Speciali JG. Headache and symptoms of temporomandibular disorder: an epidemiological study. Headache 2010;50:231-41.

19. Vazquez-Delgado E, Schmidt JE, Carlson CR, DeLeeuw R, Okeson JP. Psychological and sleep quality differences between chronic daily headache and temporomandibular disorders patients. Cephalalgia 2004;24:446-54.

20. Kampe T. Function and dysfunction of the masticatory system in individuals with intact and restored dentitions. A clinical, psychological and physiological study. Swed Dent J 1987;42:1-68.

21. Özdinç S, Ata H, Selçuk H, Can HB, Sermenli N, Turan FN. Tem- 
poromandibular joint disorder determined by Fonseca anamnestic index and associated factors in 18-to 27-year-old university students. Cranio 2020;38:327-32.

22. Warren MP, Fried JL. Temporomandibular disorders and hormones in women. Cells Tissues Organs 2001;169:187-92.

23. Bruguiere F, Sciote JJ, Roland-Billecart T, Raoul G, Machuron F, Ferri $\mathrm{J}$, et al. Pre-operative parafunctional or dysfunctional oral habits are associated with the temporomandibular disorders after orthognathic surgery: an observational cohort study. J Oral Rehabil 2019;46:321-9.

24. Okeson JP. Long-term treatment of disk-interference disorders of the temporomandibular joint with anterior repositioning occlusal splints. J Prosthet Dent 1988;60:611-6.

25. Lobbezoo F, Ahlberg J, Raphael KG, Wetselaar P, Glaros AG, Kato $\mathrm{T}$, et al. International consensus on the assessment of bruxism: Report of a work in progress. J Oral Rehabil 2018;45:837-44.

26. De Wijer A, Steenks MH, De Leeuw JRJ, Bosman F, Helders PJM. Symptoms of the cervical spine in temporomandibular and cervical spine disorders. J Oral Rehabil 1996;23:742-50.

27. Jiménez-Silva A, Peña-Durán $C$, Tobar-Reyes J, Frugone-Zambra $R$. Sleep and awake bruxism in adults and its relationship with temporomandibular disorders: A systematic review from 2003 to 2014. Acta Odontol Scand 2017;75:36-58.

28. Soares LG, Costa IR, Brum Júnior JDS, Cerqueira WSB, Oliveira ESD, Douglas de Oliveira DW, et al. Prevalence of bruxism in undergraduate students. Cranio 2017;35:298-303

29. Kovero O, Könönen M. Signs and symptoms of temporomandibular disorders in adolescent violin players. Acta Odontol Scand 1996;54:271-4

30. Álvarez-Melcón AC, Valero-Alcaide R, Atín-Arratibel MA, Melcon-Alvarez A, Beneit-Montesinos JV. Effects of physical therapy and relaxation techniques on the parameters of pain in university students with tension-type headache: A randomised controlled clinical trial. Neurologia 2018;33:233-43.

31. LeResche L. Epidemiology of temporomandibular disorders: implications for the investigation of etiologic factors. Crit Rev Oral Biol Med 1997;8:291-305.

\section{Asemptomatik temporomandibular düzensizliklerin klinikte Fonseca anamnestik indeksi ile araştııııması}

\section{ÖZET}

AmAÇ: Bu çalışmanın amacı, Fonseca anamnestik indeksi kullanılarak asemptomatik ve sağlıklı bireylerdeki temporomandibular düzensizliklerin saptanması (TMD) ve şiddetinin belirlenmesidir.

Gereç ve Yöntem: Çalıșmaya 135 birey (80 kadın ve 55 erkek, ortalama yaş $34.4 \pm 10.9$ ) dahil edildi. Bu bireylere Fonseca anamnestik indeksi uygulandı. Verilerin analizi Pearson'un ki-kare testi, Fisher'in kesin testi, tek yönlü ANOVA ve Spearman korelasyonu kullanılarak yapıldı.

BuLGULAR: Bireylerin \%63'ünde TMD olduğu tespit edildi. Çoğunluğu (\%40), hafif şiddetteki TMD'ye sahipti. Cinsiyet ve TMD'nin şiddeti arasında istatistiksel olarak anlamlı fark bulundu $(p=0.001)$. Temporomandibular eklem (TME) ağrısı, baş ağrısı ve emosyonel stres ile istatistiksel olarak anlamlı pozitif bir ilişki gösterdi $(r=0.312, p<0.001 ; r=0.299$, $p<0.001$, sırasıyla). TME ağrısının en güçlü pozitif korelasyonunun klik sesi ile olduğu saptandı $(r=0.443, p<0.001)$. Bruksizm, TME ağrısı ve klik sesi ile pozitif korelasyon gösterdi ( $r=0.197, p=0.022$ and $r=0.221, p=0.010$, sırasıyla).

Sonuç: Fonseca anamnestik indeksi, asemptomatik ve sağlıklı katılımcılarda bile TMD ile ilgili semptomları ve ciddiyeti tespit etmek için kullanılabilen ve klinik uygulamada hızlı sonuçlar sağlayan güvenilir bir tanı aracıdır.

ANAHTAR Kelimeler: Erken tanı; temporomandibular eklem; temporomandibular eklem bozuklukları 